\title{
The Utility of Antenatal Ultrasound in intrauterine Early Diagnosis of an Autosomal recessive Polycystic Kidney Disease in Fetus
}

\author{
Dinu-Florin Albu ${ }^{1}$, Cristina-Crenguta Albu ${ }^{2}$, Stefan-Dimitrie Albu ${ }^{3}$ \\ ${ }^{1}$ Dr. Dinu-Florin Albu, MD, Ph.D, Associate Professor, Obstetrics \& Gynecology and Medical Genetics, Expert in \\ Maternal-Fetal Ultrasound and Maternal-Fetal Medicine, ${ }^{2}$ Dr Cristina-Crenguta Albu, MD, PhD, Associate Professor, \\ Ophthalmology and Medical Genetics, ${ }^{3}$ Stefan-Dimitrie Albu, Medical Student. All are affiliated with University of \\ Medicine and Pharmacy Carol Davila, Bucharest, Romania and Alco San Clinic, Maternal-Fetal Medicine Department \\ Bucharest, Romania
}

Corresponding author: Dr. Cristina-Crenguta Albu, E-mail: stevealbu@yahoo.com

Address for Correspondence: 27A, Catedrei Street, $1^{\text {st }}$ District, 014162, Bucharest, Romania

\begin{abstract}
We report a case of a 31 year old female. Ultrasound examination showed bilateral hyperechoic kidneys with multiple cysts and poor corticomedullary differentiation. The kidneys were increased in size and color Doppler showed normal bilateral renal arteries present. Amniocentesis was performed and the fetal chromosomal analysis highlighted an inversion at the 6 p12.2. Further genetic investigations were done. Both parents were karyotiped and showed an inversion at the 6p12.2, typically for the PKHD1 gene location. After genetical councelling the parents decided to terminate the pregnancy. The autopsy confirmed the ultrasound findings.
\end{abstract}

Key words: Polycystic, Kidney, Ultrasound, Antenatal Diagnosis, Genetics

\section{Introduction}

Polycystic kidney disease (PKD) is a systemic disorder that affects kidneys and other organs, particularly the liver [1]. PKD result from the formation and progressive enlargement of cysts in the kidneys without dysplasia, usually leading to renal failure [2].

PKD is one of the most common disorders caused by monogenic mutations [3]. PKD can be inherited as an autosomal dominant trait (ADPKD) or an autosomal recessive trait (ARPKD). The autosomal dominant form of the disease is much more common than the autosomal recessive form [4].

The autosomal recessive form of PKD is much rarer and is often lethal early in life [5]. The signs and symptoms of this condition are usually apparent at birth or in early infancy [6]. PKD is usually a genetic disorder, a small percentage of cases are not caused by gene mutations. Mutations in the PKHD1 gene cause autosomal recessive polycystic kidney disease (ARPKD) [7].

Manuscript received: $24^{\text {th }}$ Nov 2014

Reviewed: $16^{\text {th }}$ Dec 2014

Author Corrected; $20^{\text {th }}$ Dec 2014

Accepted for Publication: 25 ${ }^{\text {th }}$ Dec 2014

International Journal of Medical Research and Review
People with PKD inherited in an autosomal recessive pattern have two altered copies of the PKHD1 gene in each cell. The parents of a child with an autosomal recessive disorder are not affected but are carriers of one copy of the altered gene.

\section{Case Report}

We report a case of a 31-year-old Caucasian female, pregnant for the first time, GI PI, who was referred at 22 weeks' gestation for a routine prenatal ultrasound. The couple had normal general health and was not consanguineous. There was no family history of genetic disorders.

Routine ultrasound examination at 17 weeks of pregnancy, double and triple test (AFP, uE3 and hCG), selective ultrasonography for detection of fetal abnormalities, 3D and 4D live scan with Voluson Echograph E8, amniocentesis, fetal karyotype and OFPCR were performed.

Double test was found normal at that time $(\mathrm{NT}=1,6$ $\mathrm{mm})$. The biometry of the fetus was normal for his Available online at: www.ijmrr.in 112 | P a g e 
Research Article

gestational age. Triple test was not sensitive to the presence of a possible trisomy.

Ultrasound examination at 22 weeks of gestation revealed a single fetus. Bilateral hyperechoic kidneys with multiple cysts were found with poor corticomedullary differentiation (Fig. 1 - Fig. 3).

The kidneys were increased in size and color Doppler showed normal bilateral renal arteries present. The urinary bladder was visible.

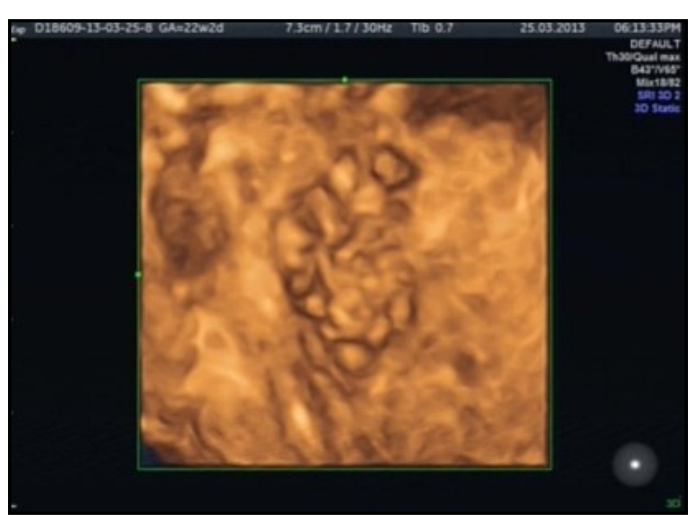

Fig. 1

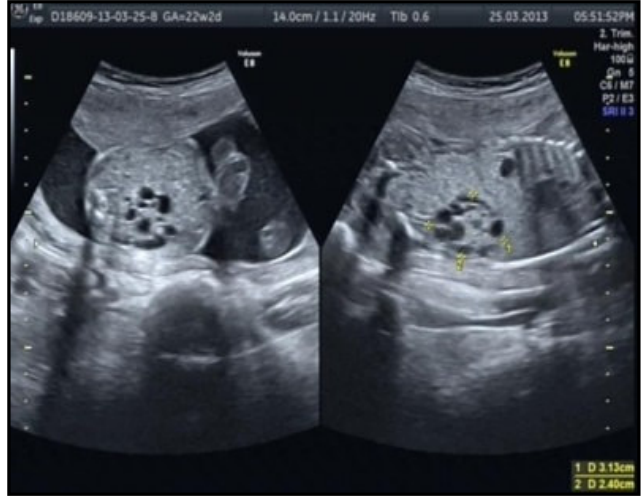

Fig. 2

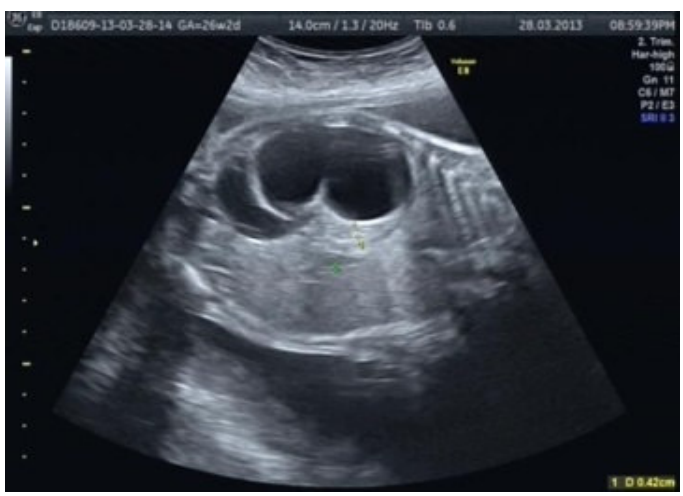

Fig. 3

Fig. 1 - 3 Bilateral hyperechoic kidneys with multiple cysts, poor corticomedullary differentiation.

An abnormal image of the fetus (male) genitalia, like hypospadias, was seen also. The parents had undergone renal ultrasound showing normal bilateral kidneys. The family was told about the possibility of autosomal recessive polycystic kidney disease (ARPKD). No family history of renal diseases on both sides was ever recorded. Amniocentesis was performed and the fetal chromosomal analysis highlighted an inversion at the $6 \mathrm{p} 12.2$. Further genetic investigations were done. Both parents were karyotyped and showed an inversion at the $6 \mathrm{p} 12.2$, typically for the PKHD1 gene location. After genetic counseling the parents decided to terminate the pregnancy. The autopsy confirmed the ultrasound findings.

\section{Discussion}

Autosomal Recessive Polycystic Kidney Disease (ARPKD) occurs in 1 in 6000 to 1 in 40,000 live births [5] and is characterized by the combination of renal cystic disease and congenital hepatic fibrosis [8]. In our case report we have not found ultrasound hepatic abnormalities [3]. The renal cystic disease typically begins in utero [6]. During fetal development, cysts also appear transiently in proximal tubules [9]. The renal cystic disease is invariably associated with biliary dysgenesis. In our case report we have not detected any ultrasound biliay abnormalities. Fibrosis of the pancreas has also been described in some patients. The clinical presentation of ARPKD is highly variable. In this case, the antenatal scan revealed symmetrical, reniform

Available online at: www.ijmrr.in 113 | P a g e 
enlargement of both the kidneys. The kidneys were diffusely hyperechogenic with loss of cortico-medullary differentiation. PKD is usually a genetic disorder, a small percentage of cases are not caused by gene mutations. The gene responsible for ARPKD is PKHD1 and has been identified on chromosome $6[3,10]$. In our rare case report both parents were karyotyped and showed an inversion at the $6 \mathrm{p} 12.2$, typically for the PKHD1 gene location. In this case, the parents are not affected but are carriers of one copy of the altered gene, but the male fetus have two altered copies of the PKHD1 gene in each cell and is affected by the ARPKD. The autosomal recessive form of PKD is rarer and is lethal early in life [5,11]. For this reason, after genetic councelling the parents decided to terminate the pregnancy.

\section{Conclusions}

Antenatal ultrasound and genetic diagnosis was very useful in the management, prognosis and detection of a fetus with a congenital grave disease. The prenatal diagnosis is necessary for the detection of fetal abnormalities to all pregnancies and especially for the risk categories.

\section{References}

1. Lonergan GJ, Rice RR, Suarez ES. Autosomal recessive polycystic kidney disease: Radiologicpathologic correlation. RadioGraphics. 2000;20:83755.

2. Traubici J, Daneman A. High-resolution renal sonography in children with autosomal recessive polycystic kidney disease. Am J Roentgenol. 2005;184(5):1630-3.

3. Igarashi P, Somlo S. Genetics and pathogenesis of polycystic kidney disease. J Am Soc Nephrol.2002;13:2384-98.

4. Adeva M, El-Youssef M, Rossetti S, Kamath PS, Kubly V, Consugar MB, Milliner DM, King BF, Torres VE, Harris PC. Clinical and molecular characterization defines a broadened spectrum of autosomal recessive polycystic kidney disease (ARPKD). Medicine (Baltimore). 2006 Jan;85(1):1-21.
5. Zerres K, Mücher G, Becker J, Steinkamm C, Rudnik-Schöneborn S, Heikkilä $\mathrm{P}$, et al. Prenatal diagnosis of autosomal recessive polycystic kidney disease (ARPKD): Molecular genetics, clinical experience, and fetal morphology. Am J Med Genet. 1998;76:137-144, 1998.

6. Albu, D., Albu, C. and Oncescu, A. (2013), P06.09: Prenatal ultrasound and genetic diagnosis of an autosomal recessive polycystic kidney disease associated with Klinefelter syndrome: rare case report. Ultrasound Obstet Gynecol, 42: 135. doi: 10.1002/uog. 12990

7. Menezes LF ${ }^{1}$, Onuchic LF. Molecular and cellular pathogenesis of autosomal recessive polycystic kidney disease. Braz J Med Biol Res. 2006 Dec;39(12):153748.

8. Kaplan BS, Kaplan P, de Chadarevian J-P, Jequier S, O'Regan S, Russo P: Variable expression of autosomal recessive polycystic kidney disease and congenital hepatic fibrosis within a family. Am J Med Genet 29: 639-647,1988.

9. Nakanishi K, Sweeney WE, Jr., Zerres K, GuayWoodford LM, Avner ED: Proximal tubular cysts in fetal human autosomal recessive polycystic kidney disease. J Am Soc Nephrol 11: 760-763, 2000.

10. Guay-Woodford LM, Muecher G, Hopkins SD, Avner ED, Germino GG, Guillot AP, Herrin J, Holleman R, Irons DA, Primack W, Thomson PD, Waldo FB, Lunt PW, Zerres K: The severe perinatal form of autosomal recessive polycystic kidney disease maps to chromosome 6p21.I-p12: Implications for genetic counseling. Am J Hum Genet 56: 1101$1107,1995$.

11. Dayananda Kumar Rajanna, Anjani Reddy, Naren Satya Srinivas, and Ankur Aneja. Autosomal Recessive Polycystic Kidney Disease: Antenatal Diagnosis and Histopathological Correlation. J Clin Imaging Sci. 2013; 3: 13

\section{How to cite this article?}

Dinu-Florin Albu, Cristina-Crenguta Albu, Stefan-Dimitrie Albu. The Utility of Antenatal Ultrasound in intrauterine Early Diagnosis of an Autosomal recessive Polycystic Kidney Disease in Fetus. Int J Med Res Rev 2015;3(1):112-114. doi: 10.17511/ijmrr.2015.i1.18 